Article

\title{
Strengthening Collaborative Food Waste Prevention in Peru: Towards Responsible Consumption and Production
}

\author{
Franklin Cordova-Buiza ${ }^{1}\left(\mathbb{D}\right.$, Alberto Paucar-Caceres ${ }^{2, *}{ }^{\infty}$, Silvia Cristina Quispe-Prieto ${ }^{3}$, \\ Andrea Pierina Rivera-Garré ${ }^{4}$, Lucero Nicole Huerta-Tantalean ${ }^{5}{ }^{\circledR}$, Jesús Enrique Valle-Paucar ${ }^{6}$, \\ Carla Vanessa Ponce de León-Panduro ${ }^{4}(\mathbb{D})$ and Toni Burrowes-Cromwell ${ }^{2}$
}

check for updates

Citation: Cordova-Buiza, F.; Paucar-Caceres, A.; Quispe-Prieto, S.C.; Rivera-Garré, A.P.;

Huerta-Tantalean, L.N.; Valle-Paucar, J.E.; Ponce de León-Panduro, C.V.; Burrowes-Cromwell, T. Strengthening Collaborative Food Waste Prevention in Peru: Towards Responsible Consumption and Production. Sustainability 2022, 14 , 1050. https://doi.org/10.3390/ su14031050

Academic Editor: Mario D’Amico

Received: 11 December 2021

Accepted: 12 January 2022

Published: 18 January 2022

Publisher's Note: MDPI stays neutral with regard to jurisdictional claims in published maps and institutional affiliations.

Copyright: (c) 2022 by the authors. Licensee MDPI, Basel, Switzerland. This article is an open access article distributed under the terms and conditions of the Creative Commons Attribution (CC BY) license (https:// creativecommons.org/licenses/by/ $4.0 /)$.
1 Research and Innovation Department, Universidad Privada del Norte, Lima 15306, Peru; franklin.cordova@upn.edu.pe

2 Business School, Manchester Metropolitan University, Manchester M15 6BH, UK; tonicromwell.tni@gmail.com

3 Escuela Profesional de Enfermeria, Universidad Nacional Jorge Basadre Grohmann, Miraflores 23000, Peru; squispep@unjbg.edu.pe

4 Sinba Sura SAC, Lima 15074, Peru; andrea@sinba.pe (A.P.R.-G.); carlavplp@hotmail.com (C.V.P.d.L.-P.)

5 Faculty of Business, Universidad Privad a del Norte, Lima 15306, Peru; lucerohuerta05@hotmail.com

6 Escuela Profesional de Administración Turístico-Hotelera, Universidad Privada de Tacna, Tacna 23003, Peru; neverend1718@icloud.com

* Correspondence: a.paucar@mmu.ac.uk

\begin{abstract}
Inefficient management and handling of organic waste generated by the food service sector is a big global challenge. In addition to the negative environmental impacts of food waste, the effect of the amount of food that is wasted when it is not handled properly is even more alarming. This is particularly when we witness the millions of people who suffer from lack of food and malnutrition. The objective of this research is to examine the situation of organic waste management in food services in the cities of Lima and Tacna in Peru. Using a quantitative methodological approach to waste management, a questionnaire was administered to a sample of 67 restaurants in both cities. The survey results suggest that the restaurants do not carry out the separation or reuse of organic waste. Furthermore, the main methods of disposal include providing surpluses to the staff and sending organic waste to the sanitary landfill and slaughterhouses. There is also a lack of awareness and training about the importance of organic waste management. From the restaurants interviewed, although around $60 \%$ claimed to segregate them, only $28 \%$ measured organic waste using a manual control and $18 \%$ indicated that they weighed the waste for management purposes. As a corrective measure for this deficiency, the production of an awareness video was created to improve decision-making and support change.
\end{abstract}

Keywords: food waste; hospitality; circular economy; responsible consumption; sustainability; Peru

\section{Introduction}

A third of the food produced in the world is wasted; this is equivalent to 1.3 billion tons that are thrown away [1]. In Latin America and the Caribbean, this loss represents $15 \%$ of food produced per year [1]. In addition, according to the Economic Commission for Latin America and the Caribbean (ECLAC) [2], in this same region, there has been an increase in the rate of poverty and extreme poverty, reaching 33.7\% and $12.5 \%$, 209 million and 78 million, respectively. This also translates to individuals and communities who do not have the resources to feed themselves. On the other hand, a study published by the FAO in 2013 estimated that food wasted or lost globally is equivalent to $250 \mathrm{~km}^{3}$ of water used, which represents $6 \%$ of the total water extracted and $30 \%$ of the land used for agricultural products in the world. Likewise, these wastes and losses represent $8 \%$ of greenhouse gas (GHG) emissions [3]. 
These figures have led to the elaboration of an ambitious but necessary universal agenda to guide the world towards environmental protection. The thrust is towards prosperity for all, among others, which is reflected in the UN Sustainable Development Goals (SDGs). According to SDG 12, the aim is to halve the amount of food waste per capita at the retail and consumer levels by 2030. Additionally, the problem of food waste is associated with the aims of SDGs 6 (Sustainable Water Management) and 13 (Climate Change) [4]. The latter is reinforced by the international treaty of the Paris Agreement, which establishes the objective of keeping the increase in global temperature below $2{ }^{\circ} \mathrm{C}$ (compared to pre-industrial levels) and to continue the effort to keep it below $1.5^{\circ} \mathrm{C}$ as soon as possible.

Meanwhile, in Peru, 12.8 million tons of food are wasted annually, which represents $47.6 \%$ of the total national supply [5]. At the same time, by 2020, monetary poverty affected $30.1 \%$ of Peruvians, a percentage higher by 9.9 points than in 2019 [6]. These waste streams represent a large percentage of the total solid waste generated in the country, which, in turn, represents $3.51 \%$ of greenhouse gas emissions at the national level $(6005.25 \mathrm{Gg}$ $\mathrm{CO}_{2} \mathrm{eq}$ ) [7]. Currently, Peru has expressed its commitment to reduce greenhouse gas (GHG) emissions by $30 \%$ (208.8 $\left.\mathrm{Mt} \mathrm{CO}_{2} \mathrm{eq}\right)$ by 2030. This is according to the Nationally Determined Contributions (NDCs), which consider this and solid waste as priority agenda items $[8,9]$.

In the regions of Lima and Tacna (central and southern Peru), some progress has been made regarding the management of solid waste. This is thanks to the Law of Integral Management of Solid Waste, approved by Legislative Decree No. 1278, where it is mentioned as urgent action for preventing and minimizing solid waste generation at the source and places greater emphasis on the material and energy recovery of waste [10]. Likewise, there are Law No. 30988- "Law that promotes the reduction and prevention of food losses and waste" and Law No. 30498 - "Law that promotes the donation of food and facilitates the transport of donations in situations of natural disasters.". These have given rise to private initiatives that propose mechanisms for the recovery of organic waste and also for transformation into value-added products destined for the animal feed industry and agriculture. One such initiative has been Sinba Sura SAC [11]. Through its environmental impact reports, this company has included important data on the generation of organic waste for restaurants and canteens within the hospitality and catering sector (Table 1).

Table 1. Average daily generation of organic waste, collected by Sinba Sura SAC in the period 2019-2021.

\begin{tabular}{cc}
\hline Sector & Average Daily (kg) \\
\hline Food Industry & 96.86 \\
Hospitality and Catering-Restaurants & 81.08 \\
\hline
\end{tabular}

Fuente: Sinba Sura SAC [2021].

Although there has been some progress, there is still much to be accomplished. This is particularly with regards to a progressive circular food economy $(\mathrm{CfE})$. According to the food waste hierarchy, a circular economy applied to the food sector requires the prevention of all waste in the first place. In each instance, it would mean ensuring the use of any surplus food, held at its maximum value (e.g., food redistribution for humans or as byproducts). This is opposed to simply dumping organic waste in a landfill (Ellen MacArthur Foundation) [12]. One recent report indicates that the world is only adhering to $8.6 \%$ in terms of such circular measures [3]. It therefore reinforces the urgency of accelerating the transition towards a nonlinear production system, in which materials and resources (such as water and energy) are kept at their highest value usage for as long as possible $[13,14]$.

It also allows for achieving Peru's NDC goals at a much faster rate. There are several variables that impede progress. One of these factors is the lack of awareness and guidance to management and other personnel at the top of the food service sector. This research seeks to contribute to this challenge by examining the situation of organic waste management 
on the part of restaurants and other food catering services in the cities of Lima and Tacna in Peru.

\section{Food Waste Management Literature Review}

There are many theories that have attempted to tackle the complexity of diverse food variables involved in waste management. The literature confirms that food waste is a global problem. Furthermore, it has been reported that developed countries present greater food waste than developing countries, that is to say, that the generation of waste is actually related to the wealth of the countries [15]. The term "food losses" is related to the preparation and processing process, while the term "food waste" refers to waste in the distribution and consumption stages [16,17].

Within the food service sector, waste has a definite negative impact on the environment. For example, this could be especially if arable areas are used for food that will never be consumed. Likewise, within the hospitality and catering arena, food waste also means a loss of money for restaurants and other catering enterprises. This may be owed to the cost of the food; its high perishability as an organic resource; the cost of the worker; time spent in meal preparation and related overheads [18,19].

The implication here is that in order to study food waste management, questions should be addressed to those responsible for the restaurants. This also means an opportunity to investigate issues about the oversight of a particular business, information about the company, and the delivery of its meals and other products. It can lead to more in-depth knowledge about waste management on the part of the staff and actions taken by the restaurant (e.g., donations or reuse). These elements have been included as part of this present investigation [20].

In commenting specifically on food waste management, Teigiserova et al. [21] defined six different categories of food waste: edible, naturally inedible (bones), industrial waste, inedible due to causes (pests), inedibles due to ineffective handling, and those not counted. According to their research, these categories may be utilized in order to improve food quantification, general process management, and waste prevention.

Along the same lines, Wang et al. [22] conducted a study based on a direct weighing method and a survey of 3557 tables in 195 restaurants in 4 cities. Having assessed the amount and patterns of food waste in restaurants in China in 2015, they determined that the wasted material comprised mainly vegetables and rice. They also identified that waste varies according to consumer groups, restaurant categories, and cities. They especially noted that tourist restaurants discarded the most food.

For their part, Sakaguchi et al. [20] studied restaurants in Berkeley, CA, USA, and explained that the first effort at halting grocery wastage (before their expiration date) was to distribute them to their employees. They also indicated that $84 \%$ of restaurants used containers to store non-edible food waste and assigned it to compost. This is now more convenient as a result of a decrease in transportation costs since July 2015.

Filimonau et al. [23] inform about their interesting study, which shows that restaurants in Plovdiv, Bulgaria, do not measure the amounts of food wasted regularly. Moreover, they consider it "large but manageable" and "insignificant". This suggests that neither the environmental implications nor the harmful social problems of food waste are being considered. It also implies a clear efficiency deficit in restaurant management. Unfortunately, the relevant government support to help reduce barriers to minimize hospitality food waste and to promote industry participation does not seem to be in place.

In this regard, Närvänen et al. [24] explained that emerging companies in food waste recollection represent a timely solution in the transition towards a circular economy. This is because they are facilitating change at the institutional bases of normative and cognitivecultural pillars of society. They explain that their empowerment and participation of these actors' progress collective effort. This is key for achieving change.

On the other hand, in the research by Wen et al. [25], an internet system for the management of food waste in restaurants was implemented in the urban area of Suzhou, China. This ac- 
tivity took place from 2012 to 2015, and 6265 catering companies participated. The initiative allowed for the tagging of containers, which were then collected by 'smart' garbage trucks. The latter were specially equipped with radio frequency identification readers, weight sensors, GPS, GIS, and wireless video surveillance cameras. This experiment facilitated the online monitoring of recovered products and pollutant emissions in real-time.

Finally, with respect to all of the above, the literature introduces the circular economy as a system for maximizing the use of organic resources in hospitality and food services. As noted earlier, this production and consumption model requires conserving the value of a product. In this case, it may involve food preservation actions such as: reducing, reusing, recycling, regenerating, and renewing materials. These actions connote a shift to sustainable food systems and economic development. In making this connection between food businesses and circular practice, Dahiya et al. [26] also considered food waste as a sustainable strategy for the circular economy. According to their perspective, the idea would be to use all organic waste as renewable raw materials and to generate a spectrum of bio-based products through various bioprocesses.

\section{Methodology}

The research presents an observational, descriptive cross-sectional study that was carried out in Lima and Tacna, Peru. It was conducted between the months of March to July 2021 in food service restaurants where organic waste (leftovers and post-consumption stage) was generated. The study was financed by the Manchester Metropolitan University [MMU] of the United Kingdom, and the collaboration included national academic institutions such as Jorge Basadre Grohmann University (UNJBG) and Universidad Privada del Norte [UPN] of Peru. Sinba Sura SAC also participated as a certified company working in the area of waste management in the food industry. There was also other strategic input from municipalities that allowed us access to the database of restaurants and catering businesses.

With respect to this grouping, it comprised food service restaurants in both urban and rural country areas. The sampling was non-probabilistic and for convenience. Any restaurants, hotels, industrial canteens, and fast-food outlets that sold different types of food in Lima and Tacna (with a valid operating license) and provided service in their own premises and/or a delivery service were considered.

A total of 67 restaurants participated in the study; 29 were located in metropolitan Lima and 38 in the district of Pocollay and near Tacna. The unit of analysis was considered to be any person(s) responsible for delivering information, who met the inclusion criterion of working in a selected restaurant, and who either supervised or carried out activities that generate organic waste.

A survey was employed, and this instrument was a 30-question multiple-choice questionnaire. It was adapted from Sakaguchi et al. [20] and structured according to 4 categories. These were: administrative management of the food service restaurant, organic waste management, organic waste reduction, and the pre-pandemic context. In addition, the meaning of the most culturally used terms pertaining to food category was utilized (Table 2). It was felt that such colloquial terminology should be included in the questionnaire in order to ensure the greater clarity and understanding of the participants. The content validity of the instrument implied a review by 30 experts with many years of experience in the restaurant management field, who (in their opinion) estimated a very high content validity for the proportion of ranges coefficient (CPR) of 0.90 and the V for Ayken 96\%. Likewise, a pilot test of the instrument was applied to assess its clarity for understanding, and the observations obtained contributed to its improvement. The instrument was developed using the Google form application system, to be administered virtually. It was in place between April and May 2021. 
Table 2. Terminology used in the questionnaire based on national context.

\begin{tabular}{cl}
\hline Waste Category & \multicolumn{1}{c}{ Meaning } \\
\hline General organic waste & Includes waste and surplus food. \\
\hline Food waste & $\begin{array}{l}\text { Inedible foods: natural (such as eggshells, bones) and leftover } \\
\text { dishes, food damaged or spoiled in the cooking process, and } \\
\text { expired food. }\end{array}$ \\
\hline Surplus food & $\begin{array}{l}\text { Foods still edible, but for some reason, they were not } \\
\text { consumed, such as kitchen food leftovers (chipping) and } \\
\text { excess prepared dishes. }\end{array}$ \\
\hline
\end{tabular}

In order to organize information gathering, a flow chart was prepared for the call and subsequent invitation to participate in the research project (Figure 1).

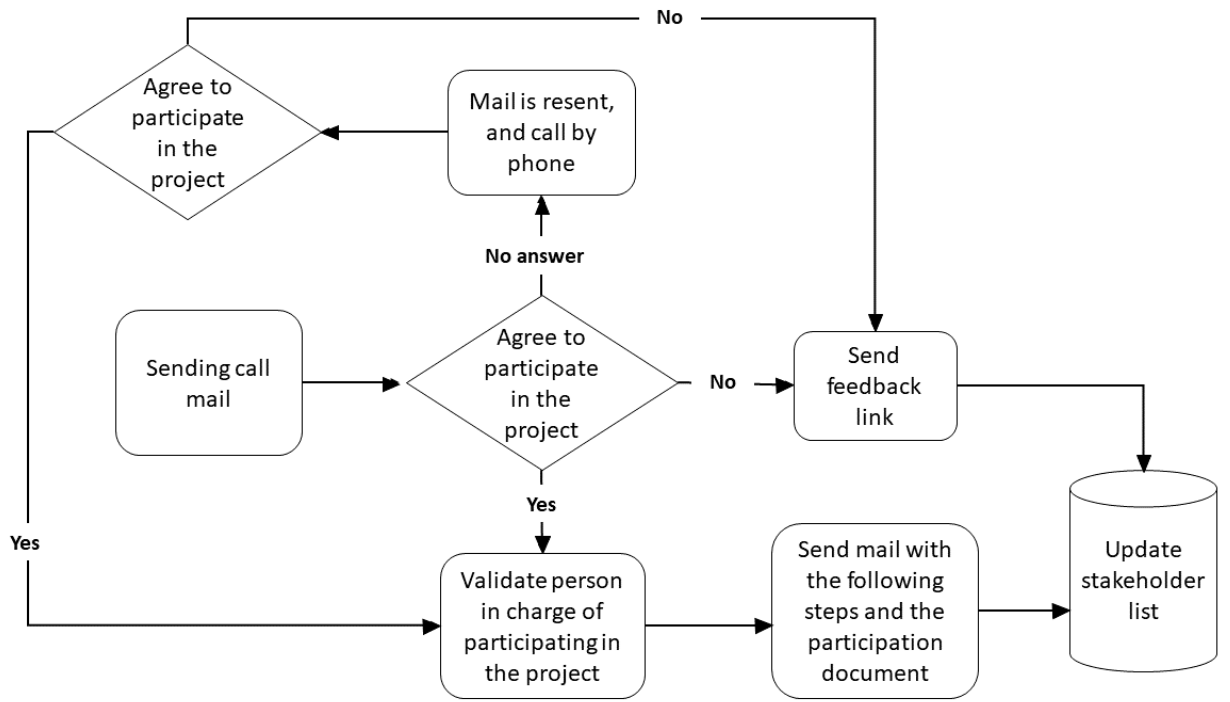

Figure 1. Call for participation flow chart.

As noted earlier, the survey was administered virtually through Google forms, and different communication strategies were used to invite participants. For example, messages were sent via social network platforms such as WhatsApp and by email. In some cases, visits were made in person with printed hard copies of the questionnaire.

Data collation entailed four stages. Stage 1 started off with an information search conducted by a combined team from the universities and Sinba Sura SAC. This stage also included managing a database with studies and international and national information on the post-consumption stage of organic waste generated in food service restaurants. In Stage 2, a diagnosis was made on the current situation of organic waste management in Peru. During Stage 3, the information was expanded for a better analysis of the current dynamics of organic waste in the cities of Lima and Tacna. The idea was to highlight preferred alternatives for action. Stage 4 corresponded to the intervention route for the transition towards a circular economy. This was with respect to the dynamics of organic waste in both cities. A video was created as part of awareness building, and this visual showed the nature and current challenges of organic waste. It also outlined alternatives to prevention and ways to implement the reuse of organic waste. The preparation and launch of the video took place between the months of August and October. Figure 2 outlines the key milestones. 

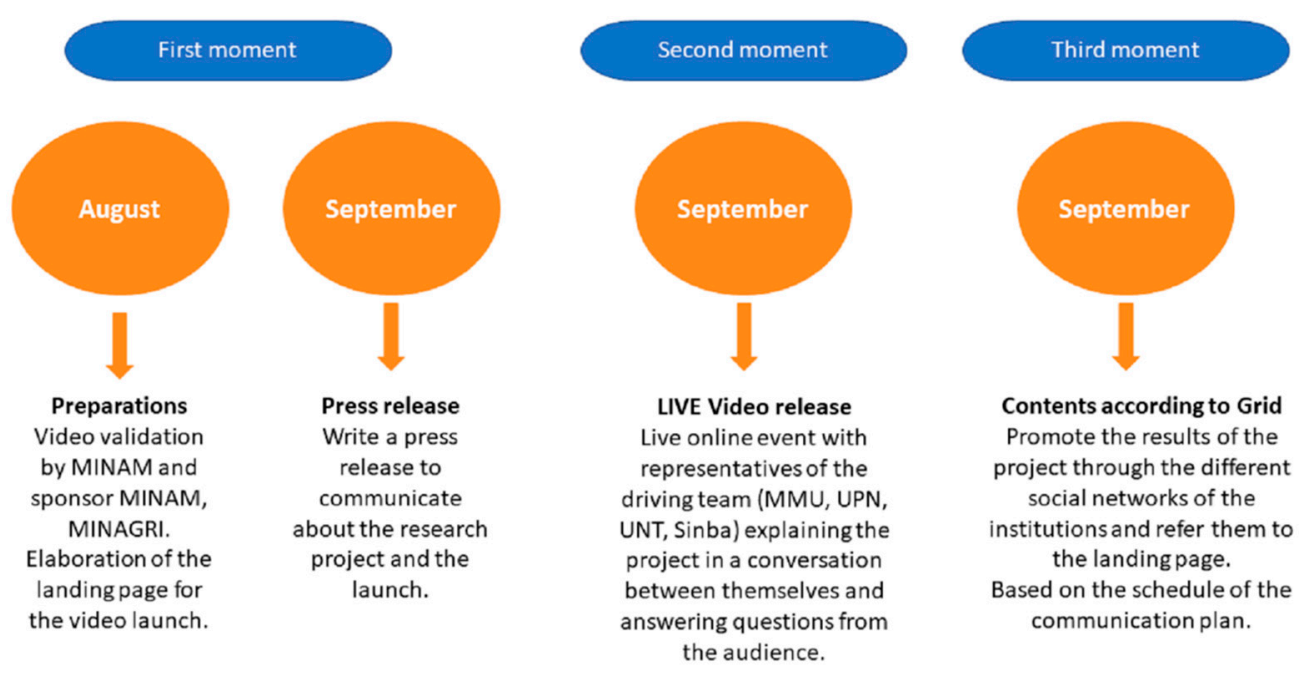

Figure 2. Definite moments for the video launch.

\section{Ethical Protocol}

The intellectual property of any authors referenced in this work (i.e., regarding the theories and results of their studies) was respected. We made sure to cite researchers correctly and to specify all bibliographic sources. The project narrative was delivered to the appropriate research departments of the participating universities. This then required a sign-off as a confirmation of commitment to this research investigation. The survey questionnaire did not address controversial issues, and consent from the representatives of the food service/restaurants was requested prior to distributing the questionnaire. Additionally, the identity of the respondents remains confidential. Respecting anonymity was paramount. It should be noted that wherever possible, the authors and interviewers have completed a virtual training exercise about the responsible conduct of research.

\section{Results}

The following section presents the main results based on the four parts of the questionnaire. A complete set of tables of results can be found in Appendix A.

\subsection{Administrative Management of the Food Service Restaurant}

Most of those surveyed were managers (25.4\%) and owners (25.4\%) of the restaurant. This was followed by administrators (16.4\%). Likewise, $65.7 \%$ offered creole food-typical of Peruvian dishes; $10.4 \%$ provided other varied dishes, and $6 \%$ offered both ceviche (typical Peruvian marine dish) and Amazonian food, respectively. Additionally, 86.6\% offered a fixed-price table service, $79.1 \%$ delivery services, $10.4 \%$ other types, including variable-price buffets $(4.5 \%)$ and fixed-price buffets $(4.5 \%)$.

Regarding the number of workers, $82.1 \%$ of the restaurants had between 1 and 20 workers and $6 \%$ between 41 and 60 employees. Likewise, before the pandemic, the daily flow of customers was 71-120 (29.6\%) and 20-70 (26.9\%) customers. At the moment of writing, the daily flow of customers has decreased, the first place being between 20-70 $(46.3 \%)$ and $71-120(14.9 \%)$ customers (Table A1).

\subsection{Organic Waste Management}

According to Table 3, the kitchen is the source of the highest organic waste $(68.66 \%)$. This was followed by the pre-production phase $(56.72 \%)$ and the post-consumption phase. The latter refers to leftover food and menu waste from the diner (43.28\%). Furthermore, waste sources were not limited to internal activities. Consumer behavior is a huge influence on what happens to food beyond the kitchen. In terms of specifics, the main areas generating organic waste were in the food production process; when peeling vegetables, tubers, and 
fruits generating peels; natural losses due to the portion vs. yield issue of certain products; and during the cleaning processes for vegetables, meat, fish, and shellfish.

Table 3. The main areas of organic waste generation in food businesses of Lima and Tacna, 2021.

\begin{tabular}{ccc}
\hline Main Areas of Organic Waste Generation & $\mathbf{N}^{\circ}$ & $\%$ \\
\hline Restaurant reception point & 11 & 16.42 \\
Pre-production phase (almost always starts 2 h before opening kitchen) & 38 & 56.72 \\
Kitchen & 46 & 68.66 \\
Storage & 0 & 0 \\
Unpredictable demand (excess of meals prepared per day) & 7 & 10.45 \\
Customers (leftover plate) & 29 & 43.28 \\
\hline
\end{tabular}

On the other hand, more than half of those surveyed stated that they "do not" measure the amounts of their organic waste $(56.70 \%)$, followed by $28.36 \%$ that stated "yes", with measurements using a manual control (inventories). Finally, 17.91\% claimed to weigh their waste and, 5.97\% actually invested in a specialized software system. Some participants (5.97\%) in the alternative "Others" section mentioned ways in which they use their organic waste, such as: using waste in orchards, for feeding pets, composting, handling financial ratios, or hiring the Sinba Sura SAC company for removal of organic waste (Table 4).

Table 4. Ways of measuring the amounts of organic waste in food businesses of Lima and Tacna, 2021.

\begin{tabular}{ccc}
\hline Ways of Measuring & $\mathbf{N}^{\circ}$ & \% \\
\hline Yes, we have a specialized software system & 4 & 5.97 \\
Yes, through manual control (inventory-waste) & 19 & 28.36 \\
Yes, we weigh the waste & 12 & 17.91 \\
No & 40 & 56.70 \\
Others $\left(^{*}\right)$ & 4 & 5.97 \\
\hline
\end{tabular}

$\left({ }^{*}\right)$ When asked, the participants indicated in advance some actions regarding their organic waste management: residues used in allotments/orchards and poultry farms; use as pets' food, the rest is for composting; designed their own financial ratio; using Sinba Sura SAC.

Respondents provided approximate measurements of the average daily amount of food surplus (Table A2), being less than 1, 1-2, and 20-100 kg. Likewise, the average daily amount of waste was approximately between $1-6,7-12$, and $15-25 \mathrm{~kg}$. On the other hand, $9 \%$ do not measure or do not know the average daily amount of their waste. It is worth noting that this variation depended on the size and facilities of the restaurant. Additionally, respondents shared that the days with the highest volume of organic waste were: Saturday (74.6\%), Friday (55.2\%), and Sunday (41.8\%) (Table A3).

With respect to the separation of organic waste into surplus and waste (Table 5), some respondents stated that "yes" they perform the corresponding segregation (59.7\%). Amongst the most outstanding strategies of waste separation were having colored containers (52.5\%); use of a bucket with lid, and assigning personnel for sorting the materials.

In contrast to this, $40.3 \%$ do not separate their organic material into surpluses and waste. Some respondents mentioned reasons for this, such as: "It is not customary"; "It has not been organized"; "There is no need"; "Everything goes to an only container to recycle"; "Because there are no surpluses or there are very few"; "Lack of time and personnel"; "For prevention of COVID"; "Lifetime of the products we offer"; "Due to ignorance" or problems with the "storage"; "For prevention of COVID"; "Lifetime of the products we offer"; "Due to ignorance" or problems with "storage". 
Table 5. Separation of organic waste into surplus food and food waste in food businesses of Lima and Tacna, 2021.

\begin{tabular}{ccc}
\hline Organic Waste Separation & $\mathbf{N}^{\circ}$ & $\mathbf{\%}$ \\
\hline Yes & 40 & 59.7 \\
No & 27 & 40.3 \\
Total & 67 & 100.0 \\
\hline Ways of Separating Organic Waste into Surplus Food and Food Waste & $\mathbf{N}^{\circ}$ & $\mathbf{\%}$ \\
\hline We have colored containers & 21 & 52.5 \\
We have personnel for classification & 7 & 17.5 \\
Others: bucket with lid (*); packaged surpluses donated or frozen; we & 12 & 30.0 \\
recycle and compost/feed for animal farms & 40 & 100 \\
Total & &
\end{tabular}

Note: $\left(^{*}\right)$ This option was the most popular.

\subsection{Organic Waste Reduction}

In speaking about the main actions for the prevention of organic waste, there were: portion control $(67.2 \%)$, staff training $(41.8 \%)$, and cooking on demand $(40.3 \%)$. In contrast to these approaches, $6 \%$ do not take any action (Table 6 ).

Table 6. Organic waste prevention actions in food businesses of Lima and Tacna, 2021.

\begin{tabular}{ccc}
\hline Organic Waste Prevention Actions & $\mathbf{N}^{\circ}$ & $\mathbf{\%}$ \\
\hline Cook on demand & 27 & 40.3 \\
Portion control & 45 & 67.2 \\
Staff training & 28 & 41.8 \\
Short menu & 19 & 28.4 \\
Creation of dishes using unconsumed inputs & 10 & 14.9 \\
No action & 4 & 6.0 \\
Others: use the same inputs on all menus $\left.{ }^{*}\right)$; daily inventories of critical & & \\
products; what is left over from the buffet is given to the workers; waste to \\
farms; reinforcement and constant monitoring of training and compliance \\
with procedures. \\
Note: $\left(^{*}\right)$ This option was the most popular.
\end{tabular}

The most popular disposal methods for food waste (Table 7) included: using containers and disposing of the waste for municipal public collection on route to the landfill (49.3\%); additionally, $37.3 \%$ directed waste towards the pig farms (informal breeding spaces for pigs and where food waste is reused to feed them); and 9\% made compost. The main reasons why food waste action was not implemented as best practice were: lack of knowledge; it is not considered necessary; lack of space; there is no program or system; too little quantity; absence of supervisory personnel; lack of willingness to do it; products' shelf life or lifetime; and lack of staff time.

In the case of the most used disposal methods for food surplus (Table 7), $58.2 \%$ give the remainder of the prepared food to the staff, $28.4 \%$ dispose of it via the landfill, and $20.9 \%$ deliver it to recyclers working in pig farms. Among the main reasons why food surpluses are not used or donated were: surpluses are distributed among the staff; they only prepare what is necessary; food safety 'Menu Safe'; the cost to dispose of it is lower. Some persons admitted that they did not know how to take advantage of or donate these surpluses.

Actions taken to influence the behavior of the customers were: offering 'to-go'/doggie bags, tapers/food containers (76.12\%); offering different menu portion sizes $(25.37 \%)$; conducting awareness campaigns for customers $(16.42 \%)$; posting informative messages $(16.42 \%)$ and other actions $(7.46 \%)$. However, $5.97 \%$ do not take any action or do not know how to do so (Table 8). 
Table 7. Waste and surplus food disposal method in food businesses of Lima and Tacna, 2021.

\begin{tabular}{|c|c|c|}
\hline Food Waste Disposal Method & $\mathbf{N}^{\circ}$ & $\%$ \\
\hline Containers and municipal public collection (landfill) & 33 & 49.3 \\
\hline Composting (compost production) & 6 & 9.0 \\
\hline Hiring of solid waste operating company (private) & 14 & 20.9 \\
\hline \multirow{2}{*}{$\begin{array}{l}\text { Others: pig farms }\left(^{*}\right) \text {; food for consumption animals; used for animals such as ducks and pigs owned by the restaurant; } \\
\text { feeding of animals; shopping centers have segregation and storage centers; external person is in charge of waste } \\
\text { collection; it is given to the family for animal consumption (ducks) and bones for dogs; gatherer worker. } \\
\text { Total }\end{array}$} & 25 & 37.3 \\
\hline & 78 & \\
\hline Food Surplus Disposal Method & $\mathbf{N}^{\circ}$ & $\%$ \\
\hline Give the remainder of prepared food to staff & 39 & 58.2 \\
\hline Donate to charities & 8 & 11.9 \\
\hline Use for other meals & 8 & 11.9 \\
\hline Composting (compost production) & 5 & 7.5 \\
\hline Disposing of it via the landfill & 19 & 28.4 \\
\hline Pay surplus food reuse service & 4 & 6.0 \\
\hline Delivery to recyclers-pig farmers & 14 & 20.9 \\
\hline \multirow{2}{*}{$\begin{array}{l}\text { Others: give gifts to people in need; municipality takes all the waste; Sinba works it; it is disposed of as waste; food for } \\
\text { consumption animals; feeding little animals; management of protections and operating systems makes the calculation } \\
\text { and management of surpluses efficient. } \\
\text { Total }\end{array}$} & 7 & 10.4 \\
\hline & 104 & \\
\hline
\end{tabular}

Note: $(*)$ This option was the most popular.

Table 8. Actions taken to influence the customers' behavior in order to reduce food waste in restaurants in Lima and Tacna, 2021.

\begin{tabular}{ccc}
\hline Actions & $\mathbf{N}^{\circ}$ & $\%$ \\
\hline Awareness campaigns for customers & 11 & 16.42 \\
Informational messages & 11 & 16.42 \\
Offer to-go bags, tapers / food containers & 51 & 76.12 \\
Offer different menu portion sizes & 17 & 25.37 \\
Nothing, because I did not know & 4 & 5.97 \\
Others: productions are on-demand, customers have little & & 7.46 \\
influence; make customers aware that they can ask customer \\
service for the amount of food they are going to consume; \\
reduce portions; offer different portions on the menu. \\
Total
\end{tabular}

\subsection{Pre-Pandemic Context}

Respondents stated that before the pandemic, a greater amount of organic waste was generated $(83.6 \%)$, and the main days for this were Saturdays $(79.10 \%)$ and Sundays (71.64\%) (see Tables A4 and A5).

The most common waste generated before the pandemic was chicken bones, fruit peels, unusable vegetable scraps, and leftover dishes. These waste groupings were followed by fish bones, skin, and shells. With respect to the surpluses, more pieces of vegetables, stews, broths, prepared salad, fruits, French fries, and chicken were produced. Some individuals mentioned having few surpluses and highlighted their intention to control their surplus.

\section{Discussion}

The flow of customers pre-pandemic and, subsequently, during the pandemic has fallen from 71 to 120 customers ( $29.9 \%$ ) to $20-70$ customers ( $46 \%$ ), respectively. This shows a clear decrease in visits is a consequence of the compulsory lockdowns and social isolation measures. In terms of the COVID-19 alerts and their impact, there has been a reduced business capacity for restaurants of $60 \%$ in regions under moderate alert and $40 \%$ for those that have reached the very high alert level [27].

In relation to the type of service provided by the restaurants, most of the respondents offered a fixed-price table service (86.6\%) and delivery (79.1\%). Eckert Matzembacher et al. [28] found that restaurants with a fixed-price table service generated greater amounts 
of waste than those with variable-price buffets (with the least volume of waste). Others with fixed-price buffet/dining rooms had a higher amount of waste, although at a medium level. In our case, we found that the restaurants that offered varied-price buffets generated more surpluses (up to $300 \mathrm{~kg}$ ) than those that provided a fixed-price table service (up to $200 \mathrm{~kg}$ ). However, it should be noted that this depended on the size of the restaurant.

Interestingly, the results on the areas that produced the highest organic waste (kitchen, pre-production, and diner areas) as well as its main causes (preparation, preparation) coincided with the study by Quested et al. (2011), as cited in Linder et al. [29] In that scenario, $20 \%$ of household food waste corresponded to unavoidable waste (shells, shells, and bones). Likewise, Eckert Matzembacher et al. [28] showed similar values of unavoidable residues per dish (pits and fruit peels). Filimonau et al. [30] indicate that organic waste comes mainly from kitchens and plate waste. Both areas tend to contribute equally to the generation of organic waste. In any case, Martin-Rios et al. [31] argued that restaurants have full control over the generation of waste from non-customer activities such as food storage, packaging, and cooking.

Another point to observe is the excessive preparation of food that can occur in buffetstyle restaurants or in those that provide catering services [32]. This may explain the results, where $43.28 \%$ indicated that the greatest generation of waste comes from the leftovers on the customers' plates. The amount of waste increases when restaurants tend to forecast demand inefficiently and overproduce their dishes [30]. Likewise, the study by Wang et al. [22] found that 53\% of customers occasionally asked for the remainder of their food as a 'doggie bag' / 'to-go', whereas 5\% never did. According to Lavén [33], the most important factors are attitudes towards the environment, beliefs about the environment, and moral norms. This suggested that consumers with a greater concern for the environment tended to waste less.

Similarly, the importance of general public awareness about food waste and the need for information about specific environmental issues is highlighted. The aspiration is that this would support a shift of voluntary behavior and pro-environmental attitudes towards stopping business and other food waste [34]. Additionally, erecting informative messages on dining tables might help to motivate customers to choose more sustainable consumption [35].

When it comes to preventative actions, portion control, staff training, 'cook on demand', short menus, reusing organic waste for the creation of dishes, and gifting surplus food to workers were identified. These strategies correlate with those mentioned by Filimonau et al. [30], who also added that owner-managers also collaborated with reliable suppliers. This was in order to guarantee the efficient delivery of fresh food, thereby avoiding meal rejections.

Overall, measuring the amount of organic waste was not actively applied in the restaurants that were studied. Unfortunately, one consequence could be that any inappropriate treatment of organic waste could become a source of contamination. This may lead to poor sanitation and wider environmental hazards or negative economic impacts [36].

Fifty percent $(50 \%)$ of the restaurants generated less than $1 \mathrm{~kg}$ of daily food surplus and between $1 \%$ to $6 \%$ of waste. Apparently, this is due to the fact that they use a deliberate policy of reducing surpluses and waste. There is also a significant number of restaurants that generated between 20 to $100 \mathrm{~kg}$ of surplus and between 7 and $50 \mathrm{~kg}$ of waste. Likewise, the results are lower than those reported by the Peru-based Sinba Sura SAC Company [11], which reports an average daily organic waste generation of $81.08 \mathrm{~kg}$ for restaurants and $96.86 \mathrm{~kg}$ for industrial canteens. On this note, Carmona Cabello et al. [32] argued that in any case, a third of the food produced usually ends up in the garbage.

On the topic of separating the organic waste into surplus and material to be otherwise discarded, the strategy is essentially a segregation process. This facilitates the recycling of food waste and other redistribution. As a result, it is advisable to isolate as much matter as possible as this allows material recovery, which can then be used as pig food once appropriate procedures are also followed [37]. The results show that $59.7 \%$ of respondents 
implemented this system, as opposed to $40.3 \%$ who did not bother. These results do not match the studies by Sánchez et al. [38] and Dávila Torres and Espinoza Altamirano [39]. These researchers noted in their investigations that there was a general failure of restaurants to take any action in this regard.

We noted earlier a practical system for separating organic waste into surplus and waste that is based on color-coding. In this instance, $52.5 \%$ of respondents claimed the use of colored containers, followed by $30 \%$ who used other methods, such as buckets with a lid. Others reported that they donated or froze food materials. Even so, it is worth pointing out that the suitable disposal of organic waste (i.e., in appropriate containers) is not always carried out. This is not only a Peruvian problem. In their study, Schneider [40] came to the same conclusion in observing that there was also inadequate storage in at least four Swedish restaurants and school canteens.

With respect to food waste disposal methods, the results indicated that the majority of material really ended up in landfills. According to Filimonau et al. [30], it is much easier for managers to dispose of meal waste than to make some kind of sustainable alternative. AS to the surveyed restaurants that were sending their waste to the pig farms for animal feed, other researchers have sanctioned this action. For example, Yang et al. [41] also mention that restaurant food waste can be used to feed farm animals and for the production of biogas and compost. However, they highlighted the necessity of a legal framework to support this.

The most mentioned disposal methods for food surpluses were: giving what is left of prepared food to staff; disposing surpluses to landfills; and delivery to recyclers for pig food. Sakaguchi et al. [20] also indicated the first method (giving surplus to staff) as the most used to eliminate excess food. However, the staff did not know the exact amount and type of food they were allowed to take, and, sometimes, this impacted the effectiveness of the method.

Carmona Cabello et al. [32] highlighted that one way to reuse surpluses from the overproduction of dishes or use of ingredients was through traditional gastronomy. There is also the opportunity to engage in the principles of a circular food economy. For example, one practice-'salmorejo' - entails a Cordovan dish that reuses hard bread that is left over. Another local practice involves diverting food waste from landfill. In this instance, the Peru Food Bank (BAP) rescues food products and organic resources from agricultural and other food businesses. These items are then redistributed to those in need. The Bank only receives foodstuff that is not yet expired and in good condition. For example, the items might only have packaging errors, have been used for short-term promotion, or be food that could not be exported [42]. At the same time, enforcing these requirements can be problematic for restaurants.

In Peru, $7.57 \%$ of waste pickers are scavengers; in addition to this contingent of waste pickers, $87 \%$ work informally, independently, and in very unhealthy, precarious conditions [43]. Feeding animals with organic waste is a desirable way to avoid this practice. Furthermore, it is classified as a better option when compared to composting and anaerobic digestion because it has fewer environmental and health impacts [44,45]. Additionally, using waste as animal feed can reduce the impacts on land use for producing organic animal feed. Even so, the support of companies and industries would be necessary $[45,46]$ for formal, efficient coordination that complies with any operational regulations.

Teigiserova et al. [21] proposed the following hierarchy of actions that underscore circular practice: prevention of food surpluses in the first instance, followed by reuse for human consumption; then, reuse for animal feed; subsequently, nutrient recovery (e.g., anaerobic digestion, composting, soil application); energy recovery (e.g., biofuel production, incineration with energy recovery). The disposal of any remaining waste involving landfills and incineration (even without energy recovery) comes as a last resort. Upon reflection, although the results of this study show that the most used measure employed by the food businesses in question is reuse for human consumption, the second most used measure actually corresponds to the last category above-disposal in the landfill. 
It is common for improvements to be implemented at the operational level in order to reduce or eliminate surplus food. These span activities pertaining to menu content and structure, order taking, portions served, and attempts to reduce and recycle subsequent organic waste. However, it should be noted that not all of these actions are ideal for every type of restaurant [31]. Another strategy referred to earlier in this study related to using a system to quantify organic waste that is generated daily. While these may be helpful in reducing the quantity of waste, they can be complications and challenges in implementing them and keeping a high commitment from kitchen and other staff. Furthermore, in some cases, they are not very precise [20]. According to Lavén [33], in order to change the behavior which contributes to generating restaurant food waste, managers must raise awareness about the environmental impacts. Apart from behavioral change, others put forward the view that there is also a solid argument for business savings as a result of cutting back on waste (Lipinski et al. [47]).

We have already established that the actions most likely to be adopted by restaurants to influence the customer behavior included: offering take-out bags, tapers/food containers.; different portions; and alerting customers through campaigns and other messaging. These results were similar to those of Cárdenas and Peña [48], who identified amongst the main strategies in hospitality and accommodation, activities such as providing guidelines for guests and other stakeholders, strengthening environmental awareness measures, and promoting recycling through programs or campaigns. Hat said, in the case of Peru, although hotels are responsible for managing their waste, if there is no adequate environmental education for the clientele, the strategies will not be successful. This is because of negative cultural influences and also because the relative absence of environmental education is notorious. The same might be said about the catering and food service dimension of hospitality businesses.

With regards to the amount of organic waste generated before the pandemic, in food service restaurants, more than $80 \%$ of those surveyed mentioned that before the start of the pandemic, a greater amount of organic waste was generated; this is understandable because these enterprises were operating at full capacity. There were no restrictions or other confinement impacting business. This suggests a direct relationship between the volume of waste, the surplus produced, and the type of related waste flow. On this note, whilst organic waste has the potential to be reused, the point should be made that "surplus food is reused exclusively for humans, while food waste can be reused by animals (and never by humans)" [21] (p. 4). This is an important distinction in the food waste hierarchy.

\section{Conclusions}

The type of service offered, as well as the type of food, can influence the dynamics of organic waste generation in food service restaurants in Lima and Tacna. Most of the restaurants that participated provided a table service with a fixed price, which (according to the literature) is the category that generates the greatest amount of waste.

The work areas that created the greatest amount of organic waste pertained to the kitchen and to plate waste from customers. However, given this scenario, most restaurants do not measure organic waste. This suggests a lack of management of the appropriate indicators and readiness factors to achieve reduction objectives. It also suggests a general lack of interest at this level in getting involved and taking action.

The most recurring method to eliminate organic waste is sending it to the landfill. This is contrary to the ideal practice of a hierarchical pyramid for food waste recovery. Furthermore, although the landfill is the method that requires the least effort, it is certainly the one that generates the greatest environmental and health impacts. According to the hierarchy standard, reduction at source and recovery for human consumption and/or animal consumption are more preferable.

On the other hand, the respondents mentioned some barriers to change that precluded actions such as the separation or reuse of waste and surpluses. These included (but were not limited to) comments such as "it is not a common practice", "there is no need to do 
so", "a little amount is generated", and "lack of time and personnel". This shows that the measurement and management of organic waste are not seen as an important business investment by entrepreneurs in the gastronomic sector.

Given the panorama of the dynamics in the management of organic waste in both cities, some suggestions for change entail promoting and implementing a circular business practice. Additionally, the role of municipal, regional, and national authorities is paramount. This is in terms of supportive policy frameworks and endorsing the sustainable business actions of restaurants. This would be through financial support and support tax rebates, rewards, or reductions.

The COVID-19 pandemic and the restrictions of social distancing significantly hampered our initial surveying preference for in-person engagement. Therefore, we were limited in fostering a more in-depth and personal approach to data collation. Additionally, we were deprived of the usual possibility of making observations about the particular restaurant or catering business. This would normally be afforded when conducting onsite surveys.

\section{Limitations of the Study, Future Actions, and Implications}

Although we recognize that this study took place under quite unique circumstances, this study has one important limitation: the study used a small sample of restaurants in two regions of Peru, which prevents inferences to the large set of restaurants in the country. Additionally, it is preliminary research about the subject, and further investigation about the management of organic waste in food service restaurants in different Peruvian cities is now timely. This would be especially significant if they are applied to companies with a larger client pool. In addition, there is an opportunity to research household food waste and the food production industries. This information would allow comparisons between studies and would allow us to obtain generalizable conclusions in various economic sub-sectors.

Finally, we are pleased to announce that the research team is planning a special event, together with the launch of a video. Our aspiration is to raise national awareness about the research topic and to disseminate the results to our original respondents, business representatives, and other key stakeholders.

Author Contributions: Conceptualization, S.C.Q.-P., F.C.-B., A.P.R.-G., L.N.H.-T., J.E.V.-P., C.V.P.d.L.-P. and A.P.-C.; methodology, S.C.Q.-P., F.C.-B. and A.P.-C.; software, S.C.Q.-P. and L.N.H.-T.; validation, L.N.H.-T.; formal analysis, S.C.Q.-P. and F.C.-B.; investigation, S.C.Q.-P., F.C.-B., A.P.R.-G., L.N.H.-T., J.E.V.-P., C.V.P.d.L.-P. and A.P.-C.; resources, A.P.R.-G. and J.E.V.-P.; data curation, L.N.H.-T.; writingoriginal draft preparation, S.C.Q.-P., F.C.-B., A.P.R.-G., L.N.H.-T., J.E.V.-P. and C.V.P.d.L.-P.; writingreview and editing, A.P.-C., T.B.-C. and L.N.H.-T.; visualization, A.P.-C.; supervision, A.P.-C.; project administration, S.C.Q.-P. and A.P.-C.; funding acquisition, A.P.-C. All authors have read and agreed to the published version of the manuscript.

Funding: This research was carried out as part of the Manchester Metropolitan University Grant: QR Global Challenges Research Fund 2021: Project/“Strengthening Collaborative Food Waste Prevention in Colombia and Peru: Towards Responsible Production and Consumption". The project was led by the Manchester Metropolitan University (MMU) of the United Kingdom, with the participation of Jorge Basadre Grohmann University (UNJBG), Universidad Privada del Norte (UPN), and Sinba Sura SAC company.

Institutional Review Board Statement: Not applicable Informed.

Informed Consent Statement: Informed consent was obtained from all subjects involved in the study data.

Data Availability Statement: The data presented in this study are available upon request from the corresponding author.

Conflicts of Interest: The authors declare no conflict of interest. 


\section{Appendix A}

Table A1. Main characteristics of food businesses of Lima and Tacna, 2021.

\begin{tabular}{|c|c|c|}
\hline Respondent's Position & $\mathbf{N}^{\circ}$ & $\%$ \\
\hline Manager & 17 & 25.4 \\
\hline Owner & 17 & 25.4 \\
\hline Administrator & 11 & 16.4 \\
\hline Type of Food Offered & $\mathbf{N}^{\circ}$ & $\%$ \\
\hline Creole food-typical dishes & 44 & 65.7 \\
\hline Others & 7 & 10.4 \\
\hline Amazonian food & 4 & 6.0 \\
\hline Cevichería (fish and seafood) & 4 & 6.0 \\
\hline Staff Number & $\mathbf{N}^{\circ}$ & $\%$ \\
\hline $1-20$ & 55 & 82.1 \\
\hline $41-60$ & 4 & 6.0 \\
\hline $\begin{array}{l}\text { Pre-Pandemic Customers Flow } \\
\text { per Day }\end{array}$ & $\mathbf{N}^{\circ}$ & $\%$ \\
\hline $71-120$ & 20 & 29.6 \\
\hline $20-70$ & 18 & 26.9 \\
\hline $221-420$ & 3 & 13.4 \\
\hline $\begin{array}{c}\text { Current Flow of Customers per } \\
\text { Day }\end{array}$ & $\mathbf{N}^{\circ}$ & $\%$ \\
\hline 20-70 & 31 & 46.3 \\
\hline Not precise & 13 & 19.4 \\
\hline $71-120$ & 10 & 14.9 \\
\hline Type of Service & $\mathbf{N}^{\circ}$ & $\%$ \\
\hline Fixed price table service & 58 & 86.6 \\
\hline Delivery & 53 & 79.1 \\
\hline Others $\left(^{*}\right)$ & 7 & 10.4 \\
\hline Variable price buffet & 3 & 4.5 \\
\hline Fixed price buffet & 3 & 4.5 \\
\hline
\end{tabular}

(*) "Others" include take away; food concessionaire in a camp; service of ecosystem experiences at the table; pick up in-store; cooking classes; menu order; dishes requested by customers.

Table A2. Average amount (kg) of surplus food and food waste generated daily in food businesses of Lima and Tacna, 2021.

\begin{tabular}{ccc}
\hline Amount of Surplus Food (kg) & $\mathbf{N}^{\circ}$ & \% \\
\hline Less than 1 & 34 & 50.7 \\
$1-2 \mathrm{~kg}$ & 7 & 10.4 \\
$3-4 \mathrm{~kg}$ & 4 & 4.0 \\
$5-10 \mathrm{~kg}$ & 3 & 4.5 \\
$10-20 \mathrm{~kg}$ & 3 & 13.4 \\
$20-100 \mathrm{~kg}$ & 9 & 9.0 \\
$100-500 \mathrm{~kg}$ & 6 & 1.5 \\
$500-1500$ & 1 & 100 \\
Total & 67 & $\%$ \\
\hline Amount of Food Waste (kg) & $\mathbf{N}^{\circ}$ & 3.0 \\
\hline $0-5 \mathrm{~kg}$ & 2 & 26.9 \\
$1-6 \mathrm{~kg}$ & 18 & 22.4 \\
$7-12 \mathrm{~kg}$ & 15 & 19.4 \\
$15-25 \mathrm{~kg}$ & 13 & 9.0 \\
$30-50 \mathrm{~kg}$ & 6 & 4.5 \\
80-100 kg & 3 & 4.5 \\
$400 \mathrm{~kg}$ kg & 3 & 1.5 \\
Total & 1 & 9.0
\end{tabular}


Table A3. Days which generate more organic waste in food businesses of Lima and Tacna, 2021.

\begin{tabular}{ccc}
\hline Days That Generate More Organic Waste & $\mathbf{N}^{\circ}$ & $\mathbf{\%}$ \\
\hline Saturday & 50 & 74.6 \\
Friday & 37 & 55.2 \\
Sunday & 28 & 41.8 \\
\hline
\end{tabular}

Table A4. Amount of organic waste before the pandemic in food businesses of Lima and Tacna, 2021.

\begin{tabular}{ccc}
\hline Amount of Organic Waste before Pandemic & $\mathbf{N}^{\circ}$ & $\%$ \\
\hline Greater amount of organic waste & 56 & 83.6 \\
Lower amount of organic waste & 9 & 13.4 \\
The same amount of organic waste & 2 & 3.0 \\
Total & 67 & 100 \\
\hline
\end{tabular}

Table A5. Days that generated more organic waste before the pandemic.

\begin{tabular}{ccc}
\hline Days That Generated More Organic Waste before the Pandemic & $\mathbf{N}^{\circ}$ & $\mathbf{\%}$ \\
\hline Saturday & 53 & 79.10 \\
Sunday & 48 & 71.64 \\
Friday & 41 & 61.19 \\
\hline
\end{tabular}

\section{References}

1. Organización de las Naciones Unidas para la Alimentación y la Agricultura [FAO]. Pérdidas y Desperdicios de Alimentos en América Latina y el Caribe. 2014. Available online: http:/ / www.fao.org/americas/noticias/ver/es/c/239393/ (accessed on 12 July 2021).

2. Comisión Económica para América Latina y el Caribe [CEPAL]. Panorama Social de América Latina 2020; Comisión Económica para América Latina y el Caribe [CEPAL]: Santiago, Chile, 2021.

3. Circle Economy. The Circularity Gap Report. 2021. Available online: https://www.circularity-gap.world/2021\#downloads (accessed on 4 July 2021).

4. Organización de las Naciones Unidas para la Alimentación y la Agricultura [FAO]. El Estado Mundial de la Agricultura y la Alimentación. Progresos en la Lucha Contra la Pérdida y el Desperdicio de Alimentos. Roma, 2019. Available online: http:/ / www.fao.org/3/ca6030es/ca6030es.pdf (accessed on 15 July 2021).

5. Bedoya-Perales, N.S.; Dal' Magro, G.P. Quantification of food losses and waste in peru: A mass flow analysis along the food supply chain. Sustainability 2021, 13, 2807. [CrossRef]

6. Instituto Nacional de Estadística e Informática [INEI]. Pobreza Monetaria Alcanzó al 30.1\% de la Población del país Durante el año 2020. 2021. Available online: https:/ / www.inei.gob.pe/prensa/noticias / pobreza-monetaria-alcanzo-al-301-de-la-poblacion -del-pais-durante-el-ano-2020-12875/ (accessed on 6 July 2021).

7. Ministerio del Ambiente [MINAM]. Tercera Comunicación Nacional del Perú a la Convención Marco de las Naciones Unidas sobre el Cambio Climático. Lima, 2016. Available online: https:/ / sinia.minam.gob.pe/documentos/tercera-comunicacion-nacio nal-peru-convencion-marco-las-naciones (accessed on 30 June 2021).

8. Gobierno del Perú. Contribuciones Determinadas a Nivel Nacional del perú Reporte de Actualización Periodo 2021-2030. 2020. Available online: https://www4.unfccc.int/sites/ndcstaging/PublishedDocuments/PeruFirst/ReportedeActualizaci\{ó\}ndela sNDCdelPer\{ú\}.pdf (accessed on 30 June 2021).

9. Ministerio del Ambiente [MINAM]. La Contribución Nacional del Perú-iNDC: Agenda Para un Desarrollo Climáticamente Responsable. 2016. Available online: https://www.minam.gob.pe/cambioclimatico/wp-content/uploads/sites/11/2015/12 /LA-CONTRIBUCI\{Ó\}N-NACIONAL-DEL-PER\{Ú\}1.pdf (accessed on 30 June 2021).

10. Presidencia de la República del Perú. Decreto Legislativo $\mathrm{N}^{\circ}$ 1278. Ley de Gestión Integral de Residuos Sólidos. Diario Oficial El Peruano, 2016. Available online: https:/ / busquedas.elperuano.pe/download/url/decreto-legislativo-que-aprueba-la-ley-degestion-integral-d-decreto-legislativo-n-1278-1466666-4 (accessed on 1 July 2021).

11. Sinba Sura SAC. Sinba_Por un Mundo sin Basura-Empresa Socioambiental. 2021. Available online: https://sinba.pe/ (accessed on 6 July 2021).

12. Ellen MacArthur Foundwation. Cities and a Circular Economy for Food. 2009. Available online: https:/ /www.ellenmacarthurfo undation.org/assets/downloads/Cities-and-Circular-Economy-for-Food_280119.pdf (accessed on 20 October 2021). 
13. European Commission. Communication from the Commission to the European Parliament, the Council, the European Economic and Social Committee and the Committee of the Regions. Closing the loop-An EU action plan for the Circular Economy. Brussels, 2015. Available online: https: / / eur-lex.europa.eu/resource.html?uri=cellar:8a8ef5e8-99a0-11e5-b3b7-01aa75ed71a1.0 012.02/DOC_1\&format=PDF (accessed on 10 July 2021).

14. Carus, M.; Dammer, L. The Circular Bioeconomy-Concepts, Opportunities, and Limitations. Ind. Biotechnol. 2018, $14,83-91$. [CrossRef]

15. Secondi, L.; Principato, L.; Laureti, T. Household food waste behaviour in EU-27 countries: A multilevel analysis. Food Policy 2015, 56, 25-40. [CrossRef]

16. Organización de las Naciones Unidas para la Alimentación y la Agricultura [FAO]. Global Food Losses and Food Waste-Extent, Causes and Prevention. Roma, 2011. Available online: http:/ / www.fao.org/3/i2697e/i2697e.pdf (accessed on 12 July 2021).

17. Kummu, M.; de Moel, H.; Porkka, M.; Siebert, S.; Varis, O.; Ward, P.J. Lost food, wasted resources: Global food supply chain losses and their impacts on freshwater, cropland, and fertiliser use. Sci. Total Environ. 2012, 438, 477-489. [CrossRef] [PubMed]

18. Parfitt, J.; Barthel, M.; Macnaughton, S. Food waste within food supply chains: Quantification and potential for change to 2050. Philos. Trans. R. Soc. B Biol. Sci. 2010, 365, 3065-3081. [CrossRef]

19. Garrone, P.; Melacini, M.; Peergo, A.; Pollo, M. Opening the Black Box of Food Waste Reduction. Food Policy 2014, 46, 129-139. [CrossRef]

20. Sakaguchi, L.; Pak, N.; Potts, M.D. Tackling the issue of food waste in restaurants: Options for measurement method, reduction and behavioral change. J. Clean. Prod. 2018, 180, 430-436. [CrossRef]

21. Teigiserova, D.; Hamelin, L.; Thomsen, M. Towards transparent valorization of food surplus, waste and loss: Clarifying definitions, food waste hierarchy, and role in the circular economy. Sci. Total Environ. 2020, 706, 136033. [CrossRef] [PubMed]

22. Wang, L.-E.; Liu, G.; Liu, X.; Liu, Y.; Gao, J.; Zhou, B.; Gao, S.; Cheng, S. The weight of unfinished plate: A survey based characterization of restaurant food waste in Chinese cities. Waste Manag. 2017, 66, 3-12. [CrossRef]

23. Filimonau, V.; Fidan, H.; Alexieva, I.; Dragoev, S.; Marinova, D.D. Restaurant food waste and the determinants of its effective management in Bulgaria: An exploratory case study of restaurants in Plovdiv. Tour. Manag. Perspect. 2019, 32, 100577. [CrossRef]

24. Närvänen, E.; Mattila, M.; Mesiranta, N. Institutional work in food waste reduction: Start-ups' role in moving towards a circular economy. Ind. Mark. Manag. 2021, 93, 605-616. [CrossRef]

25. Wen, Z.; Hu, S.; De Clercq, D.; Beck, M.B.; Zhang, H.; Zhang, H.; Fei, F.; Liu, J. Design, implementation, and evaluation of an Internet of Things (IoT) network system for restaurant food waste management. Waste Manag. 2018, 73, 26-38. [CrossRef]

26. Dahiya, S.; Kumar, A.N.; Shanthi Sravan, J.; Chatterjee, S.; Sarkar, O.; Mohan, S.V. Food waste biorefinery: Sustainable strategy for circular bioeconomy. Bioresour. Technol. 2018, 248, 2-12. [CrossRef] [PubMed]

27. Plataforma Digital Única del Estado Peruano. Coronavirus: Medidas para Enfrentar la Pandemia Según Nivel de Alerta y Región. 30 De Junio. 2021. Available online: https:/ / www.gob.pe/12365-coronavirus-medidas-para-enfrentar-la-pandemia-segun-nivelde-alerta-y-region (accessed on 30 June 2021).

28. Matzembacher, D.E.; Brancoli, P.; Maia, L.M.; Eriksson, M. Consumer's food waste in different restaurants configuration: A comparison between different levels of incentive and interaction. Waste Manag. 2020, 114, 263-273. [CrossRef]

29. Linder, N.; Lindahl, T.; Borgström, S. Using behavioural insights to promote food waste recycling in urban households-evidence from a longitudinal field experiment. Front Psychol. 2018, 9, 1-13. [CrossRef]

30. Filimonau, V.; Nghiem, V.N.; Wang, L.-E. Food waste management in ethnic food restaurants. Int. J. Hosp. Manag. 2021, 92, 102731. [CrossRef]

31. Martin-Rios, C.; Demen-Meier, C.; Gössling, S.; Cornuz, C. Food waste management innovations in the foodservice industry. Waste Manag. 2018, 79, 196-206. [CrossRef]

32. Carmona Cabello, M.; del Dorado Pérez, M.P.; Pinzi, S. Biorrefinerías. Distrib Consum 2021, 1, 86-93.

33. Lavén, L. Consumers' Food Waste Behaviour in Restaurants. 2017. Available online: https://gupea.ub.gu.se/handle/2077/52815 (accessed on 5 July 2021).

34. Filimonau, V.; Matute, J.; Kubal-Czerwińska, M.; Krzesiwo, K.; Mika, M. The determinants of consumer engagement in restaurant food waste mitigation in Poland: An exploratory study. J. Clean. Prod. 2020, 247, 119105. [CrossRef]

35. Stöckli, S.; Dorn, M.; Liechti, S. Normative prompts reduce consumer food waste in restaurants. Waste Manag. 2018, 77, 532-536. [CrossRef]

36. Fonseca Barcelos, F.N.; Cordeiro, J.; Lopes Quintão, P.; Cordeiro, J.L. Management of organic residues from the industrial restaurant of Mina Cauê, Mining Complex of Itabira/MG. Res. Soc. Dev. 2017, 6, 3-19. [CrossRef]

37. Fausto-Castro, L.; Rivas-García, P.; Gómez-Nafte, J.A.; Rico-Martínez, R.; Rico-Ramírez, V.; Gomez-Gonzalez, R.; CuarónIbargüengoytia, J.A.; Botello-Álvarez, J.E. Selection of food waste with low moisture and high protein content from Mexican restaurants as a supplement to swine feed. J. Clean. Prod. 2020, 256, 120137. [CrossRef]

38. Sánchez, C.A.; Viesca, F.C.; Sánchez, R.F.; Romero, A.T. Aprovechamiento gastronómico: Una alternativa de reutilización de los residuos sólidos del laboratorio de alimentos y bebidas de la UAEM. Rev. Latinoam. Recur. Nat. 2013, 9, $155-161$.

39. Dávila Torres, A.; Espinoza Altamirano, A.S. Propuesta de un Programa de Manejo de Residuos Sólidos Orgánicos en la Sección de Carnes y Pescados del Mercado Modelo Municipal de la Provincia de Chiclayo-2017. Universidad de Lambayeque, 2018. Available online: https:/ / repositorio.udl.edu.pe/jspui/handle/UDL/121 (accessed on 28 June 2021).

40. Schneider, F. Wasting Food-An Insistent Behaviour. Waste Soc. Context Urban Issues Solut. 2008, 8, 1-10. 
41. Yang, Y.; Bao, W.; Xie, G.H. Estimate of restaurant food waste and its biogas production potential in China. J. Clean. Prod. 2019, 211, 309-320. [CrossRef]

42. Lerner Ghitis, S. El rol del Banco de Alimentos Para Generar valor Agregado en la Agroexportación y en su Responsabilidad Social. 2019. Available online: https:/ / www.expoalimentariaperu.com/documents/Elroldelbancodealimentosparagenerarval oragregado.pdf (accessed on 25 June 2021).

43. Ciudad Saludable. Por la Ruta del Reciclaje en el Perú: Estudio Socioeconómico de la Cadena del Reciclaje. 2010. Available online: https:/ / docplayer.es / 67631156-Por-la-ruta-del-reciclaje-en-el-peru-estudio-socioeconomico-de-la-cadena-del-recicla je.html (accessed on 3 July 2021).

44. Dou, Z.; Ferguson, J.D.; Galligan, D.T.; Kelly, A.M.; Finn, S.M.; Giegengack, R. Assessing U.S. food wastage and opportunities for reduction. Glob. Food Secur. 2016, 8, 19-26. [CrossRef]

45. Salemdeeb, R.; zu Ermgassen, E.K.; Kim, M.H.; Balmford, A.; Al-Tabbaa, A. Environmental and health impacts of using food waste as animal feed: A comparative analysis of food waste management options. J. Clean. Prod. 2017, 140, 871-880. [CrossRef]

46. Zu Ermgassen, E.K.; Phalan, B.; Green, R.E.; Balmford, A. Reducing the land use of EU pork production: Where there's swill, there's a way. Food Policy 2016, 58, 35-48. [CrossRef]

47. Lipinski, B.; Hanson, C.; Waite, R.; Searchinger, T.; Lomax, J.; Kitinoja, L. Reducing Food Loss and Waste: Creating a Sustainable Food Future. In Instalment 2 of Creating a Sustainable Food Future; Working Paper; World Resources Institute: Washington, DC, USA, 2013. Available online: http:/ / www.worldresourcesreport.org (accessed on 21 October 2021).

48. Cárdenas, S.; Peña, A. Análisis de las Estrategias y Acciones Empleadas Para la Gestión Ambiental de los Residuos Sólidos en Hoteles con Énfasis en el Área de Restaurante y Eventos. Universidad Peruana de Ciencias Aplicadas, 2020. Available online: https: / / repositorioacademico.upc.edu.pe/handle/10757/654043 (accessed on 20 June 2021). 